\title{
Screening of Rice Accessions for Tolerance to Drought and Salt Stress Using Morphological and Physiological Parameters
}

\author{
Chukwudi Umego' ${ }^{1}$, Valentine Otang Ntui ${ }^{1,2}$, Effiom Eyo Ita ${ }^{1}$, Charles Opara' ${ }^{1}$ Edak Aniedi Uyoh ${ }^{*}$ \\ ${ }^{1}$ Department of Genetics and Biotechnology, University of Calabar, Calabar, Nigeria \\ ${ }^{2}$ International Institute for Tropical Agriculture, Nairobi, Kenya \\ Email: ^gen_uyoh@yahoo.com
}

How to cite this paper: Umego, C., Ntui, V.O., Ita, E.E., Opara, C. and Uyoh, E.A. (2020) Screening of Rice Accessions for Tolerance to Drought and Salt Stress Using Morphological and Physiological Parameters. American Journal of Plant Sciences, 11, 2080-2102.

https://doi.org/10.4236/ajps.2020.1112147

Received: November 7, 2020

Accepted: December 21, 2020

Published: December 24, 2020

Copyright $\odot 2020$ by author(s) and Scientific Research Publishing Inc. This work is licensed under the Creative Commons Attribution International License (CC BY 4.0).

http://creativecommons.org/licenses/by/4.0/

\begin{abstract}
Drought and salinity are the most widespread soil problems, posing a big threat to food security in rice growing regions. The present study evaluated the performance of eleven rice genotypes using morphological and physiological parameters, under induced drought and salinity conditions. The seedlings were raised in $5 \mathrm{~kg}$ of homogenous soil in plastic bags in the greenhouse. For the drought experiment, each bag was watered with $200 \mathrm{ml}$ of water twice daily until plants reached the five-leaf stage when watering was suspended for 2 weeks for the drought stressed plants but not suspended for the control plants. The experiment was a $2 \times 11$ factorial and the set up was arranged using the completely randomized design with three replications. Data were taken on Plant height, Number of tillers, leaf length, Number of green leaves, Number of dead leaves, Leaf rolling score (LRS) and Rate of water loss. The salinity experiment was set up in a similar manner except that the plants were irrigated twice a day for 2 weeks with $200 \mathrm{ml}$ of treatment solution containing either $0 \mathrm{mM} \mathrm{NaCl}$ or $75 \mathrm{mM}$ and data were collected on plant height, number of tillers, shoot fresh weight, shoot dry weight, $\mathrm{Na}^{+}$and $\mathrm{K}^{+}$concentrations, relative water content and chlorophyll content. Data from both experiments were subjected to Analysis of variance test using the GenStat software $10^{\text {th }}$ edition and the means separated using least significant difference test. Individual stress response index (ISRI) was calculated for each parameter and the means used in grouping the varieties. Of the genotypes evaluated, four (FARO 44, NERICA 2, NERICA 8 and NERICA 5) were identified as tolerant, two (NERICA 4 and FARO 57) as moderately tolerant, while the rest were found to be sensitive to drought. Equally, two varieties (FARO 44 and RAM 137) stood out in the salinity screening as tolerant varieties, five were moderately tolerant while four (FARO 64, FARO 52, NERICA 2 and FARO
\end{abstract}


55) were clearly susceptible. FARO 44 is the only genotype that showed tolerance to both drought and salinity. The identified drought and salinity tolerant rice genotypes from this study can be recommended as genetic sources for future breeding programs for drought and salinity tolerance in rice.

\section{Keywords}

Oryza sativa, Salinity Tolerance, Drought Tolerance, Morpho-Physiological Parameters, Stress Response Indices

\section{Introduction}

Rice (Oryza sativa L.) is presently one of the prominent cereal crops, accounting for more than half of human caloric intake globally and valued for its nutritional benefits. It is high in fibre, contains vitamin $\mathrm{E}$ and some minerals such as potassium, calcium, magnesium, selenium, zinc and iron and has low cholesterol and sodium contents, hence its choice as a healthy and affordable source of energy [1]. Modelling simulations estimate that agricultural production will need to double by 2050, especially with regards to high-demand staple foods such as rice, in order to sustain the growing population [2]. In Nigeria, rice has a critical role to play because it is a staple, and the country consumes about 7 million tons of rice a year. Although Nigeria is one of the major producers of rice in SSA and has the potential to combat food insecurity presently facing the country, the country has exhibited less expansion in rice production. Over the years, the Nigerian government has introduced various policies and made concerted efforts towards increasing rice production in the country, but not much success has been recorded because of low yields. The low productivity in agricultural crops including rice is mostly attributed to various abiotic stresses. The major abiotic stresses which affect rice production in Nigeria include salt toxicity, drought and Nutrient deficiency [3]. They negatively influence the survival, biomass production and yield of rice, which is a major threat to food security worldwide [4].

Drought stress affects approximately 23 million ha of rainfed rice worldwide. The situation is expected to worsen under the prevailing climate change [5] [6]. Drought stress results when water loss from the plant exceeds the ability of roots to absorb water and when the plant's water content is reduced enough to interfere with normal plant processes. Without adequate water, biological processes, such as photosynthesis, are greatly reduced. Reduced photosynthesis means reduced plant growth, including root growth, which leads to a reduction in yield. The extent to which drought affects yield depends on its intensity and the time of occurrence within the crop growth cycle [7]. Its major impact is reported to occur during the flowering and grain filling phases, resulting in significant yield losses [8]. 
Development of drought-resistant cultivars is vital for extending crop areas under low rainfall conditions and in areas without an appropriate irrigation system such as many parts of Nigeria. Furthermore, given the increasing scarcity of water resources, and competition for them, irrigation is not a practical option for alleviating drought in most of the rainfed areas. Drought management strategies therefore need to focus on maximizing extraction of available soil moisture and the efficiency of its use in crop establishment, growth, biomass and grain yield [9].

Features associated with drought-stressed plants include changes in root morphology, root penetrability and distribution; leaf rolling, reduced leaf area, stomatal closure, early flowering, early seed maturity, osmotic adjustment and increased production of Abscisic acid (ABA) [10] [11]. These can guide in the screening for drought-tolerant rice cultivars.

Soil salinity is a complex phenotypic and physiological phenomenon in plants, imposing ion imbalance or disequilibrium, ionic and osmotic stress, inducing oxidative stress and negatively influencing metabolic activities in crop plants, hence minimizing the productivity of crop plants [12]. Worldwide, more than 80 million hectares of irrigated land (representing $40 \%$ of total irrigated land) have already been rendered toxic to plants by salt [13]. Area under salt stress is rapidly increasing due to a combination of factors which include climate change, rising sea levels, excessive irrigation without proper drainage in inlands and underlying rocks rich in harmful salts amongst others. Salt stress leads to severe inhibition of plant growth and development, membrane damages, ion imbalances due to $\mathrm{Na}^{+}$and $\mathrm{Cl}^{-}$accumulation, enhanced lipid peroxidation and increased production of reactive oxygen species like superoxide radicals, hydrogen peroxide and hydroxyl radicals [14]. It has been estimated that if the current situation of increasing salinity stress would persist, it could result in the loss of $50 \%$ of present agricultural lands by 2050 [15].

In view of the enormous yield losses in rice caused by drought and salt stresses and the ongoing climate change issues, there is need to develop more upland rice lines that are tolerant to drought and salt. Although several rice lines tolerant to drought or salt have been identified worldwide [1] [6] [16]-[27], many landraces, newly improved varieties and hybrids are yet to be screened for tolerance to these abiotic stresses, especially in Nigeria. The present study assists in this direction by screening rice varieties cultivated in Nigeria for tolerance to drought and salt stresses using morphological and physiological parameters.

\section{Materials and Methods}

\subsection{Sample Collection and Experimental Sites}

Seed samples of 11 improved rice genotypes (Table 1) were collected from Africa Rice Center, Ibadan Station, Nigeria and The National Cereals Research Institute, Amakama, Abia State. The rice plants were grown in the greenhouse of the Department of Genetics and Biotechnology, University of Calabar, Calabar, 
Table 1. List of rice varieties studied and their origin.

\begin{tabular}{ccc}
\hline NAME & SPECIE & ORIGIN \\
\hline FARO 52 & Oryza sativa & Nigeria \\
FARO 44 & Oryza sativa & Taiwan province of China \\
FARO 61 & Oryza sativa & Nigeria \\
NERICA 5 & ${ }^{*}$ Oryza sativa / O. glaberimma & Cote d'Ivoire \\
NERICA 8 & ${ }^{*}$ Oryza sativa / O. glaberimma & Cote d'Ivoire \\
FARO 64 & Oryza sativa & Nigeria \\
NERICA 4 & ${ }^{*}$ Oryza sativa / O. glaberimma & Cote d'Ivoire \\
FARO 55 & ${ }^{*}$ Oryza sativa / O. glaberimma & Cote d'Ivoire \\
NERICA 2 & ${ }^{*}$ Oryza sativa / O. glaberimma & Cote d'Ivoire \\
FARO 57 & Oryza sativa & Nigeria \\
FARO 63 & Oryza sativa & Nigeria \\
RAM 137 & Oryza glaberimma & Mali \\
\hline
\end{tabular}

${ }^{\star}$ Hybrid.

Nigeria. Morphological and physiological analyses were carried out at the molecular biology laboratory of the Department of Genetics and Biotechnology, University of Calabar, Nigeria.

\subsection{Screening for Drought Tolerance}

Seeds of eleven (11) rice varieties were pre-germinated at $28^{\circ} \mathrm{C}$ by soaking in water for 2 days in labeled $50 \mathrm{ml}$ falcon tubes wrapped in aluminum foil. Thereafter, five rice seedlings per variety were transferred to plastic bags containing $5 \mathrm{~kg}$ of homogenous soil and grown in the greenhouse. Each bag was watered with $200 \mathrm{ml}$ of water twice daily until plants reached the five-leaf stage when watering was suspended for 2 weeks for the drought stressed plants, watering was not discontinued for the control plants. Data for growth parameters were taken at the end of the 2 weeks watering suspension (Zhang et al. [28] with slight modifications). The experiment was a $2 \times 11$ factorial and the set up was arranged using the completely randomized design with three replications.

Tolerance to drought was evaluated based on the following parameters: Plant height, Number of tillers, leaf length, Number of green leaves, Number of dead leaves, Leaf rolling score (LRS) and Rate of water loss. Leaf rolling score was recorded at mid-day, 15 days after stress inducement using the scale described by [29], from 1 (fresh flat leaves) to 5 (tightly rolled leaves). To detect rate of water loss under dehydration conditions, flag leaves were detached from plants and exposed to air at room temperature (approximately $24^{\circ} \mathrm{C}$ ) and weighed at 0 , $0.5,1,2,3,4,5$, and 6 hours after their detachment from the plant. This was done in 3 replications and the means used to calculate water loss rates as the percentage of initial fresh weight. Bar charts were used to highlight the effects in all cases. Data were subjected to analysis of variance test using the GenStat soft- 
ware $10^{\text {th }}$ edition and the means separated using least significant difference test. Individual stress response index (ISRI) for each parameter was calculated by dividing the trait value for a parameter under stress for a given variety by the trait value for that parameter under control. The ISRIs for all the parameters studied were added together to give the Cumulative stress response index (CSRI) for each variety [16]. The CSRI was divided by the number of parameters to obtain the mean which was used along with leaf rolling score and number of dead leaves in grouping the varieties into Highly tolerant, Tolerant, Moderately tolerant and Susceptible. The ISRI could not be meaningfully calculated for number of dead leaves because some varieties recorded zero dead leaves so the means recorded were used directly. Similarly, the leaf rolling scores were used directly because the value for control was 1.00 in all the varieties.

\subsection{Screening for Salt Tolerance}

Seeds were germinated as described in Section 2.2; thereafter five (5) rice seedlings per genotype were transplanted to labeled plastic bags containing approximately $5 \mathrm{~kg}$ of homogeneous soil obtained from the botanical garden of the University of Calabar. Three weeks after germination, the plants were irrigated for 2 weeks with $200 \mathrm{ml}$ of treatment solution $\mathrm{A}(0 \mathrm{mM} \mathrm{NaCl})$ or $\mathrm{B}(75 \mathrm{mM}$ $\mathrm{NaCl}$ ). The experiment was set up in a completely randomized design with three replications.

\subsubsection{Evaluation of Morphological Parameters}

After the two-week salinity treatment, data were taken on the following morphological parameters: Plant height, Number of tillers, Number of leaves, Number of dead leaves, shoot fresh weight and shoot dry weight. Shoot fresh weights of the plants were taken immediately after harvesting them from the greenhouse; thereafter they were oven-dried for $48 \mathrm{hrs}$ at $80^{\circ} \mathrm{C}$ and the shoot dry weights recorded.

\subsubsection{Estimation of Physiological Parameters}

The relative water content was estimated from shoot fresh and dry weights using the equation:

$$
\text { Relative Water Content }=\mathrm{SFW}-\mathrm{SDW} / \mathrm{SFW} \times 100
$$

where SFW = shoot fresh weight, SDW = shoot dry weight.

Chlorophyll was extracted from leaf tissues of control and salt treated plants, and quantified as follows: the third leaf from the base were systematically harvested from three plants and their fresh weight taken immediately. Approximately $0.05 \mathrm{~g}$ of the leaf tissues were placed in $1.5 \mathrm{~mL}$ Eppendorf tubes containing zirconia beads and then frozen in $\mathrm{U} 40 \mathrm{HEF}-80^{\circ} \mathrm{C}$ freezer. The frozen leaves were crushed using Retsch MM400 grinder. The ground tissues were mixed with $10 \mathrm{ml}$ of Dimethyl sulphoxide (DMSO) and incubated at $25^{\circ} \mathrm{C}$ for 10 min using an Eppendorf thermomixer F1.5 (VWR, USA) and then centrifuged at $10,000 \mathrm{rpm}$ for $5 \mathrm{~min}$. Two hundred (200) $\mu \mathrm{l}$ of the aqueous phase was carefully 
extracted using a pipette and put into a curvette. Absorbance values at 663 and 645 were then measured using a UV-VIS spectrophotometer, single beam 295, (Labtech, India). Chlorophyll content was then calculated as described by [30]. Chlorophyll was extracted from leaf tissues of control and salt treated plants separately.

$$
\text { Total chl }=20.2 \times \mathrm{A} 645+8.02 \times \mathrm{A} 663 \times \mathrm{V} / 1000 \times \mathrm{W}
$$

where $\mathrm{A} 663=$ Absorbance value at $663 \mathrm{~nm}$,

A645 $=$ Absorbance value at $645 \mathrm{~nm}$,

$\mathrm{V}=$ Volume of solvent used in $\mathrm{ml}$,

$\mathrm{W}=$ Weight of sample in $\mathrm{mg}$.

$\mathrm{Na}^{+}$and $\mathrm{K}^{+}$concentrations were determined according to the method of Roy et al. [31], with slight modifications. Briefly, shoot and root tissues from the plants were harvested and dried at $80^{\circ} \mathrm{C}$ for $48 \mathrm{~h}$ using UN75 plus oven (Memmert, Germany). Dry tissues were digested in $1 \%$ nitric acid overnight at $85^{\circ} \mathrm{C}$. $\mathrm{Na}^{+}$and $\mathrm{K}^{+}$concentrations were determined using an Atomic absorption spectrophotometer (Cecil, England).

\subsection{Data Analysis and Stress Response Characterization}

Morphological and Physiological data were subjected to analysis of variance tests with the means separated using Least Significance Difference tests. Mean stress response indices were calculated as described in Experiment 1.

\section{Results}

\subsection{Screening for Drought Tolerance}

The mean effects of drought stress (2 weeks) on growth parameters of eleven rice varieties are shown in Figures 1-7.

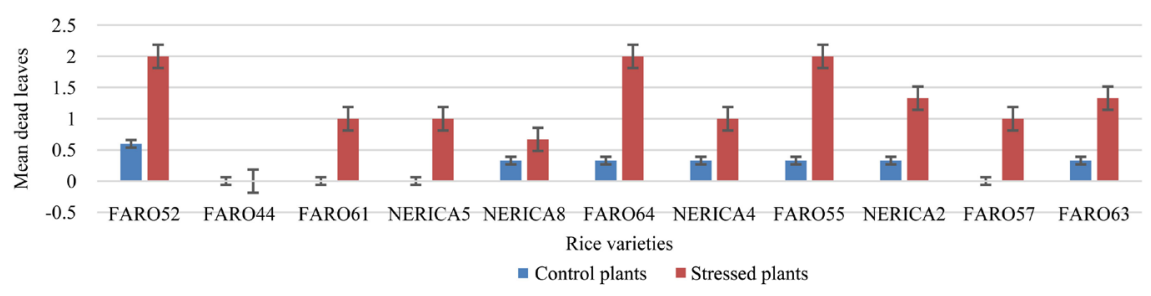

Figure 1. Mean number of dead leaves in eleven rice varieties subjected to drought treatment.

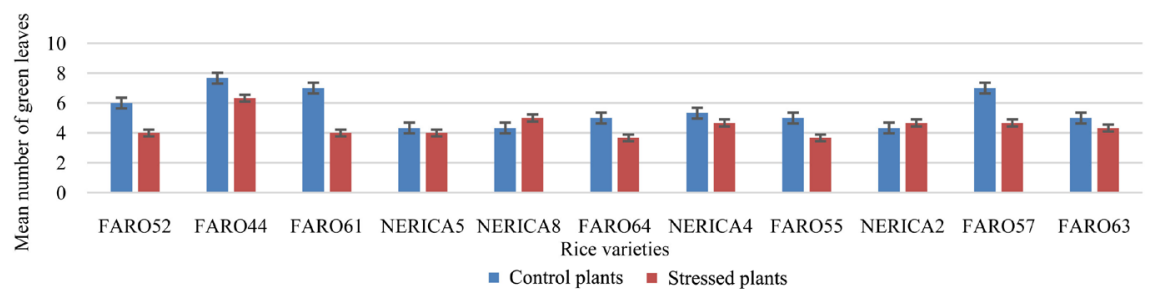

Figure 2. Mean number of green leaves in eleven rice varieties subjected to drought treatment. 


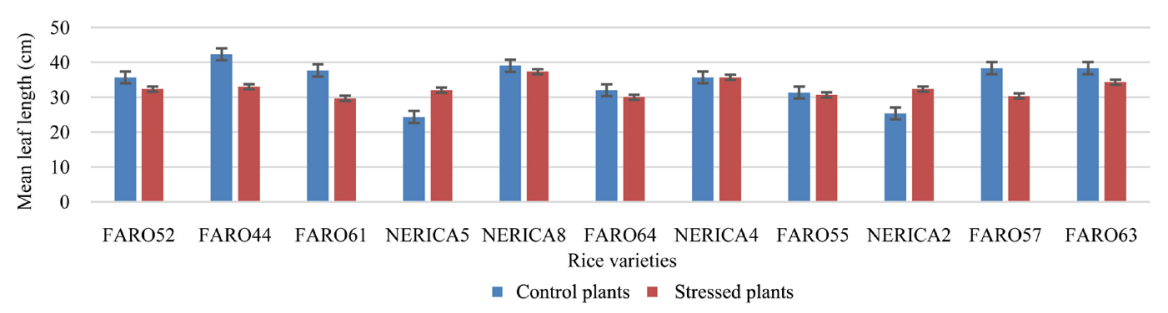

Figure 3. Mean leaf lengths in eleven rice varieties subjected to drought treatment.

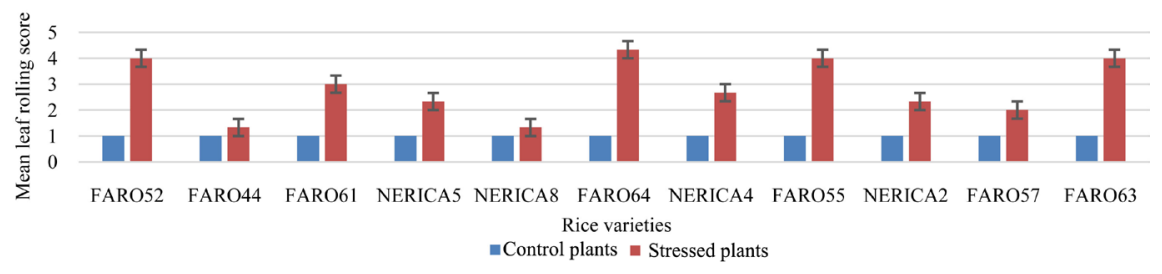

Figure 4. Mean leaf rolling score in eleven rice varieties subjected to drought treatment.

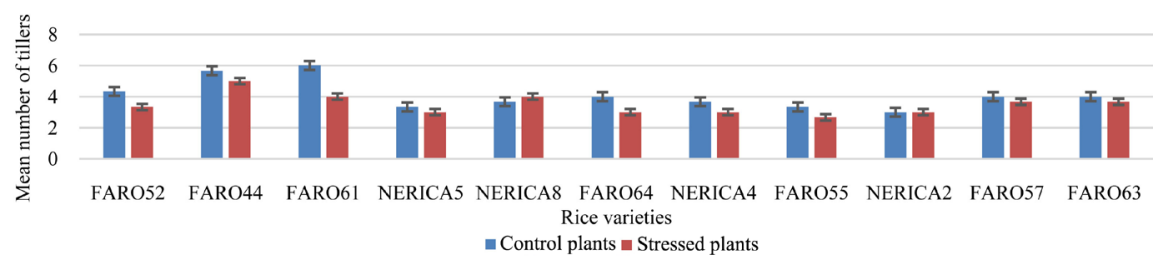

Figure 5. Mean number of tillers in eleven rice varieties subjected to drought treatment.

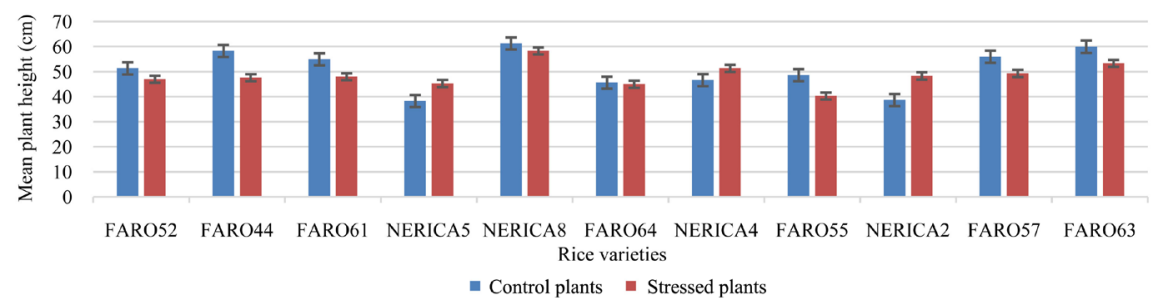

Figure 6. Mean plant heights $(\mathrm{cm})$ in eleven rice varieties subjected to drought treatment.

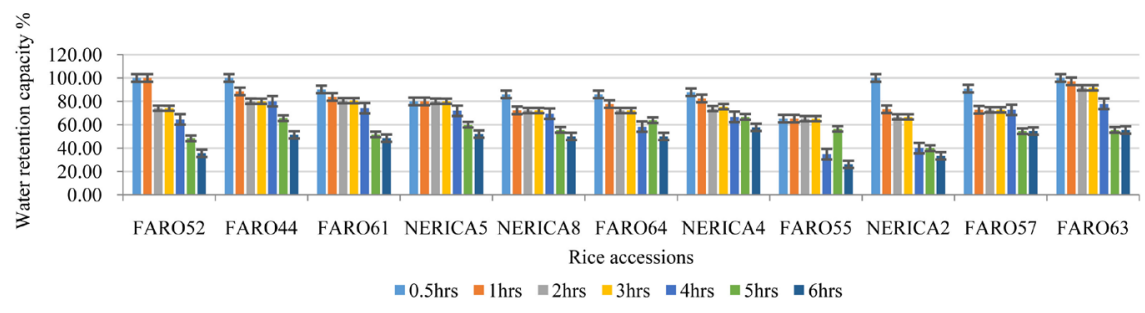

Figure 7. Water loss over time intervals in the eleven rice varieties subjected to drought.

\section{1) Number of dead leaves}

When subjected to drought conditions, a significant $(\mathrm{p}<0.001)$ reduction in number of dead leaves was observed in the rice genotypes compared with the control plants (Supplementary Table S1 \& Table S2). FARO 44 which had no dead leaf in both control and drought stressed plants and NERICA 8 with a mean of 0.67 dead leaves in stressed plants were least affected by the drought 
stress (Table 2, Figure 1, Supplementary Table S1). FARO 52, FARO 64 and FARO 55 were the worst affected with an average of 2 dead leaves per plant each (Figure 1).

\section{2) Number of green leaves}

Under drought conditions, significant $(\mathrm{p}<0.001)$ differences in number of green leaves produced were observed in the rice genotypes compared with the control plants (Supplementary Table S1 \& Table S2). NERICA 2 and NERICA 8 produced more green leaves than control and were thus the least affected by the salt stress with Individual Stress Response Index (ISRI) values of 1.07 and 1.25 respectively. NERICA 5, NERICA 4 and FARO 44 produced slightly lower numbers of green leaves compared with their controls with ISRI values of 0.92 , 0.88 and 0.83 respectively. FARO 61 was the worst affected with ISRI value of 0.57 (Table 2, Figure 2). FARO 44 recorded the highest mean number of green leaves after drought stress (6.33) (Supplementary Table S1).

\section{3) Leaf length}

Significant $(\mathrm{p}<0.001)$ differences in leaf length were observed in the rice genotypes subjected to drought stress (Supplementary Table S1 \& Table S2). NERICA 2 and NERICA 5 produced longer leaves than their controls and were thus the least affected by the salt stress with ISRI values of 1.27 and 1.32 respectively. NERICA 4, FARO 55, NERICA 8, FARO 64 and FARO 52 produced leaves with similar or slightly shorter lengths compared with their controls with ISRI values of 1.00, 0.98, 0.96, 0.94 and 0.91 respectively. FARO 44, FARO 61 and FARO 57 were the worst affected with ISRI values of $0.78,0.79$ and 0.79 respectively (Table 2, Figure 3 ).

Table 2. Final classification for drought tolerance in eleven rice varieties based on Individual stress Response Indices (ISRI)*, leaf rolling scores and number of dead leaves.

\begin{tabular}{ccccccccc}
\hline Accessions & $\begin{array}{c}\text { ISRI for } \\
\text { Green leaves }\end{array}$ & $\begin{array}{c}\text { ISRI for } \\
\text { Leaf length }\end{array}$ & $\begin{array}{c}\text { ISRI } \\
\text { for Tillers }\end{array}$ & $\begin{array}{c}\text { ISRI for } \\
\text { Plant height }\end{array}$ & $\begin{array}{c}\text { Mean Stress } \\
\text { Tolerance Index }\end{array}$ & $\begin{array}{c}\text { Leaf rolling } \\
\text { score (LRS) }\end{array}$ & $\begin{array}{c}\text { No. of Dead } \\
\text { Leaves }\end{array}$ & Group \\
\hline NERICA 8 & 1.25 & 0.96 & 1.09 & 0.95 & 1.063 & 1.33 & 0.67 & Tolerant \\
NERICA 5 & 0.92 & 1.32 & 0.9 & 1.18 & 1.08 & 2.33 & 1.00 & Tolerant \\
NERICA 2 & 1.07 & 1.27 & 1.00 & 1.25 & 1.148 & 2.33 & 1.33 & Tolerant \\
NERICA 4 & 0.88 & 1.00 & 0.82 & 1.09 & 0.948 & 2.67 & 1.00 & Moderately Tolerant \\
FARO 44 & 0.83 & 0.78 & 0.88 & 0.82 & 0.826 & 1.33 & 0 & Tolerant \\
FARO 57 & 0.67 & 0.79 & 0.92 & 0.88 & 0.815 & 2.00 & 1.00 & Moderately Tolerant \\
FARO 63 & 0.87 & 0.89 & 0.92 & 0.89 & 0.893 & 4.00 & 1.33 & Susceptible \\
FARO 64 & 0.73 & 0.94 & 0.75 & 0.99 & 0.853 & 4.33 & 2.0 & Susceptible \\
FARO 55 & 0.73 & 0.98 & 0.8 & 0.83 & 0.835 & 4.00 & 2.0 & Susceptible \\
FARO 52 & 0.67 & 0.91 & 0.77 & 0.92 & 0.818 & 4.00 & 2.0 & Susceptible \\
FARO 61 & 0.57 & 0.79 & 0.67 & 0.87 & 0.725 & 3.00 & 1.0 & Susceptible \\
\hline
\end{tabular}

*Individual Stress Response Indices (ISRI) were calculated only for number of green leaves, leaf length, number of tillers and plant height. 


\section{4) Leaf Rolling Score (LRS)}

All the control plants had LRS of 1 as expected, but when subjected to drought conditions NERICA 8 and FARO 44 were least affected and had the lowest LRS score of 1.33. On the other hand, FARO 64, FARO 63, FARO 55 and FARO 52 were the worst hit and had the highest scores ranging from 4.0 to 4.33 (Table 2, Figure 4). Leaf rolling score was significantly higher $(\mathrm{p}<0.001)$ in stressed plants compared to control (Supplementary Table S1 \& Table S2).

\section{5) Number of tillers}

There was a general reduction in the number of tillers produced under drought stress for all the genotypes except for NERICA 8 and NERICA 2 which produced more tillers than the corresponding control plants (Figure 5) and had ISRI values of 1.09 and 1.00 respectively. FARO 61 was the worst hit with ISRI value of 0.67 (Table 2).

\section{6) Plant Height (PH)}

There was a general reduction in mean plant heights of drought stressed plants compared with the controls except for NERICA 4, NERICA 5 and NERICA 2 with ISRI values of $1.09,1.18$ and 1.25 respectively. Faro 44 and FARO 55 were the worst affected relative to their controls with ISRI values of 0.82 and 0.83 (Figure 6). Under stress conditions, NERICA 8, was the tallest with height of $51.33 \mathrm{~cm}$ and this did not deviate much from control at ISRI value of 0.95 (Figure 6).

\section{7) Rate of water loss}

Faro 44 had the highest water retention capacity by retaining $80 \%-100 \%$ of its moisture in the first four hours and after 6 hours it was able to hold over $50 \%$ of its water. On the other hand, Faro 55 immediately lost $45 \%$ of its moisture in 30 min and only $26.9 \%$ moisture content was observed after just 6 hours (Figure 7).

\subsection{Screening for Salt Tolerance}

The mean effect of salt toxicity on growth parameters of eleven rice varieties is presented in Figures 8-15.

\section{1) Plant height (PH)}

A significant reduction $(\mathrm{p}<0.001)$ in plant height was observed in some of the salt treated genotypes compared with their controls (Supplementary Table S3 \& Table S4). Plant heights in RAM 137, FARO 44, FARO 55, NERICA 2 and NERICA 8 were least affected by salt treatment compared with their controls

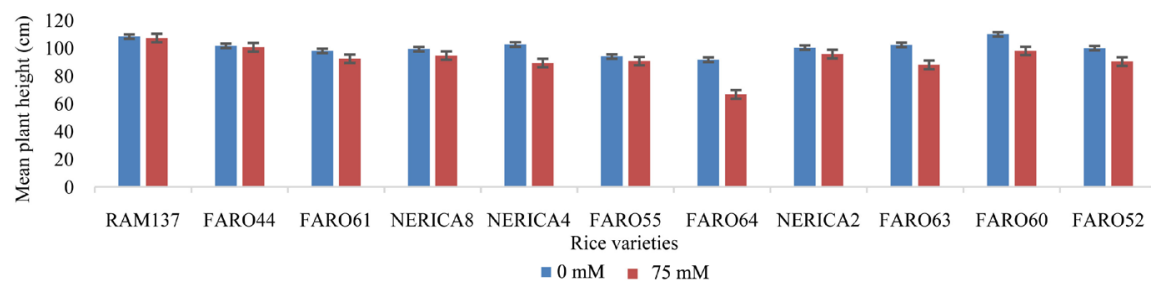

Figure 8. Mean plant height for eleven rice varieties subjected to salinity treatment. 


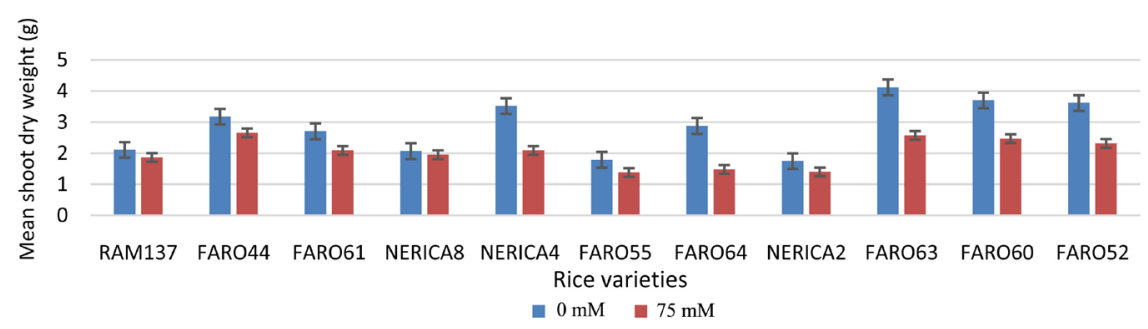

Figure 9. Mean shoot dry weight for eleven rice varieties subjected to salinity treatment.

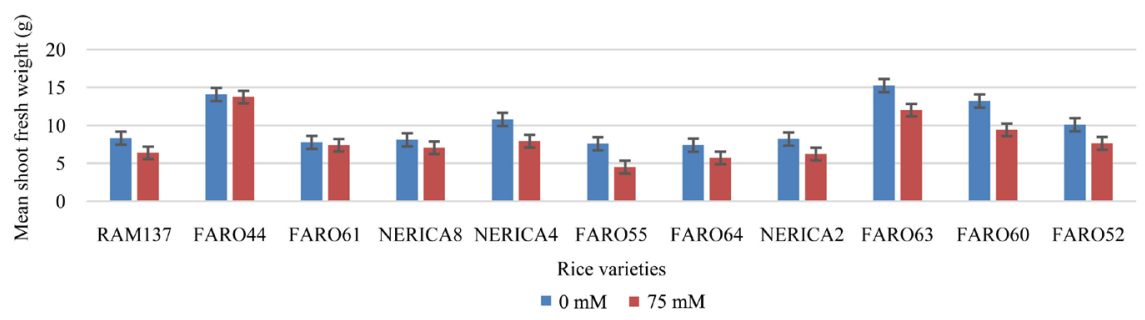

Figure 10. Mean shoot fresh weight for eleven rice varieties subjected to salinity treatment.

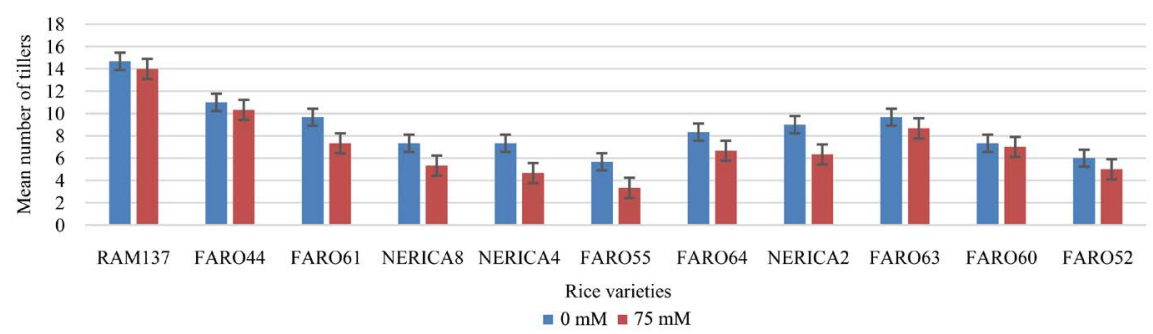

Figure 11. Mean number of tillers for eleven rice varieties subjected to salinity treatment.

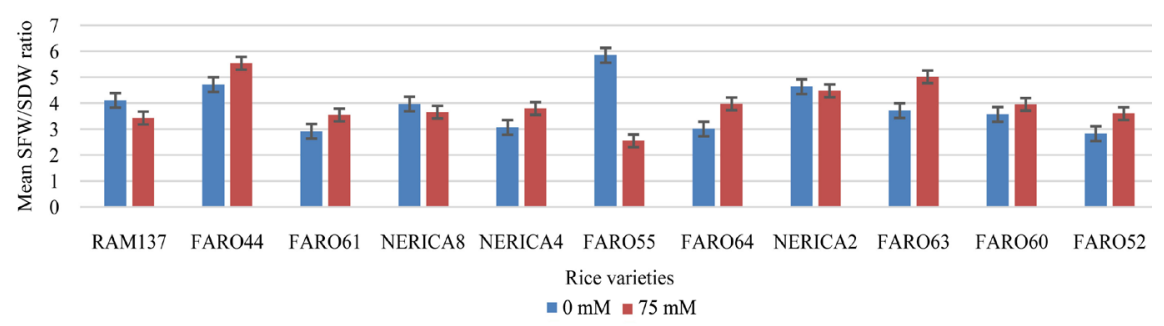

Figure 12. Mean SFW/SDW ratio for eleven rice varieties subjected to salinity treatment.

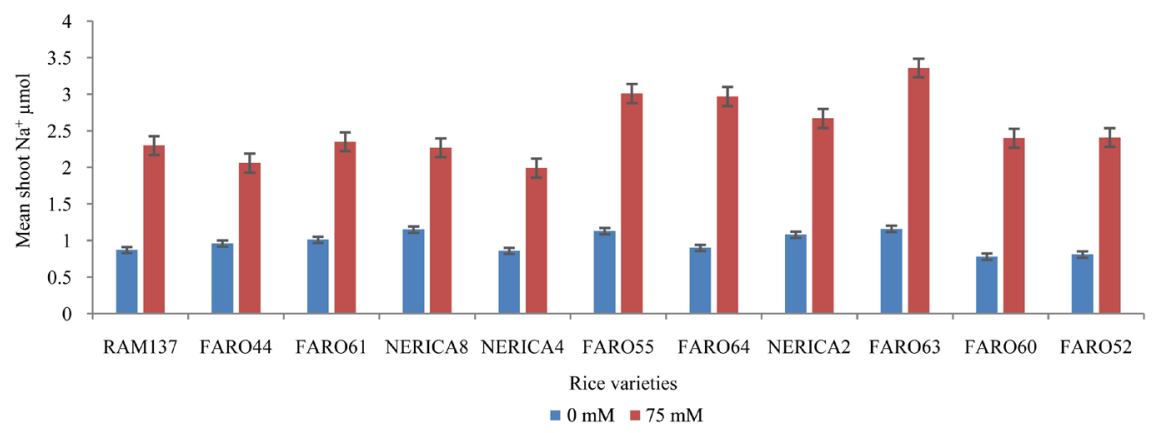

Figure 13. Mean shoot $\mathrm{Na}^{+}$content for eleven rice varieties subjected to salinity treatment. 


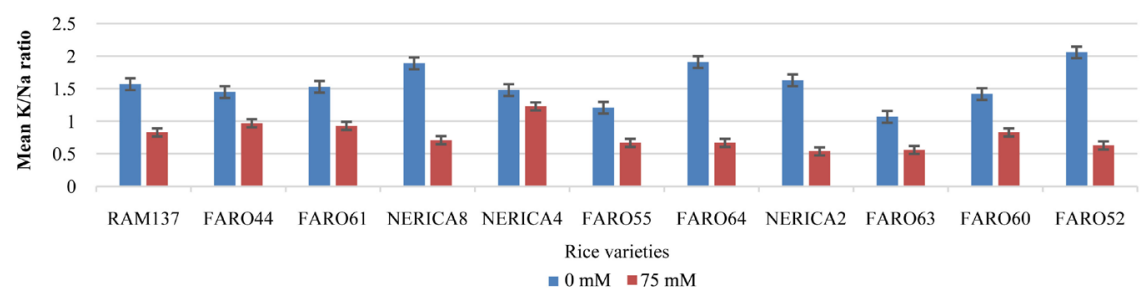

Figure 14. Mean $\mathrm{K}^{+} / \mathrm{Na}^{+}$ratio for eleven rice varieties subjected to salinity treatment.

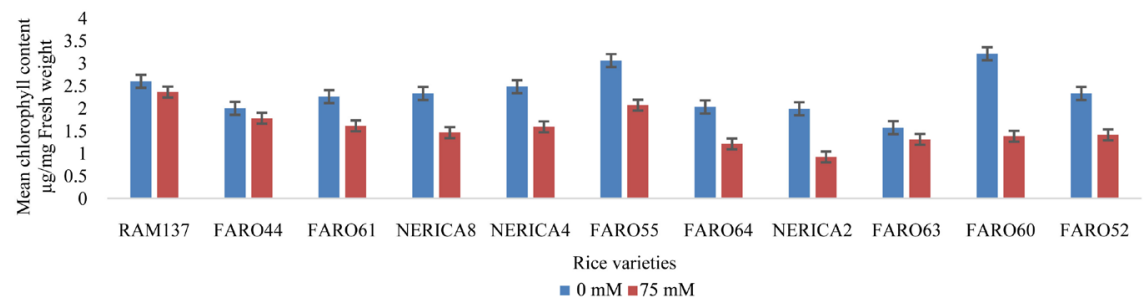

Figure 15. Mean chlorophyll content for eleven rice varieties subjected to salinity treatment.

with Individual Stress Response Index (ISRI) values of 0.99, 0.99, 0.96, 0.95 and 0.95 respectively while the worst affected was FARO 64 with ISRI value of 0.73 and a mean height of $66.67 \mathrm{~cm}$ (Table 3, Figure 8).

\section{2) Shoot Dry Weight (SDW)}

Salinity caused a significant $(\mathrm{p}<0.001)$ reduction in SDW of the rice genotypes when compared with the control plants (Supplementary Table S3 \& Table S4). SDW in NERICA 8, RAM 137 and FARO 44 were least affected by salt treatment with ISRI values of $0.95,0.89$ and 0.84 respectively while the worst affected was FARO 64 with ISRI of 0.51 and a mean shoot dry weight of $1.46 \mathrm{~g}$ in salt treated plants (Table 3, Figure 9). Under salt stress the maximum SDW was produced by FARO $44(2.66 \mathrm{~g})$, whereas the minimum was observed in NERICA 2 (1.39 g) Supplementary Table S3.

\section{3) Shoot Fresh Weight (SFW)}

Under salinity conditions a significant $(\mathrm{p}<0.001)$ reduction in SFW was observed in the rice genotypes compared with the control plants (Supplementary Table S3 \& Table S4). FARO 44, FARO 61 and NERICA 8 were least affected by the salt stress with Individual Stress Response Index (ISRI) values of 0.98, 0.95 and 0.87 respectively while the worst affected was FARO 55 with an ISRI of 0.6 (Table 3). The highest SFW was obtained in FARO 44 (14.4 g) while the least was in FARO 55 (4.52 g) (Supplementary Table S3, Figure 10).

\section{4) Number of tillers}

Salt treatment caused a highly significant reduction $(\mathrm{p}<0.001)$ in number of tillers in the treated genotypes compared with their controls (Supplementary Table S3 \& Table S4). RAM 137, FARO 44, FARO 60, FARO 63 were least affected by salt treatment compared with their controls with Individual Stress Response Indices (ISRI) of $0.95,0.94,0.95$ and 0.90 respectively (Table 3). RAM 137 produced significantly highest $(\mathrm{p}<0.001)$ mean number of tillers $(14)$ per 
Table 3. Final classification for Salt tolerance in eleven rice varieties based on Individual Stress Response Indices (ISRI) from 6 parameters and the mean scores.

\begin{tabular}{ccccccccc}
\hline Accessions & Tillers & $\begin{array}{c}\text { Plant } \\
\text { height }\end{array}$ & $\begin{array}{c}\text { Shoot Dry } \\
\text { Weight (SDW) }\end{array}$ & $\begin{array}{c}\text { Shoot Fresh } \\
\text { Weight (SFW) }\end{array}$ & K/Na & Chlorophyll & $\begin{array}{c}\text { Mean } \\
\text { Score }\end{array}$ & Group \\
\hline RAM 137 & 0.95 & 0.99 & 0.89 & 0.77 & 0.52 & 0.91 & 0.84 & Tolerant \\
FARO 44 & 0.94 & 0.99 & 0.84 & 0.98 & 0.67 & 0.89 & 0.89 & Tolerant \\
FARO 61 & 0.76 & 0.94 & 0.77 & 0.95 & 0.61 & 0.71 & 0.79 & Moderately Tolerant \\
FARO 63 & 0.9 & 0.86 & 0.63 & 0.79 & 0.52 & 0.83 & 0.76 & Moderately Tolerant \\
NERICA 8 & 0.73 & 0.95 & 0.95 & 0.87 & 0.38 & 0.63 & 0.75 & Moderately Tolerant \\
NERICA 4 & 0.64 & 0.87 & 0.59 & 0.73 & 0.83 & 0.64 & 0.72 & Moderately Tolerant \\
FARO 60 & 0.95 & 0.89 & 0.67 & 0.71 & 0.58 & 0.43 & 0.71 & Moderately Tolerant \\
FARO 55 & 0.59 & 0.96 & 0.77 & 0.6 & 0.55 & 0.68 & 0.69 & Susceptible \\
NERICA 2 & 0.7 & 0.95 & 0.8 & 0.76 & 0.33 & 0.46 & 0.67 & Susceptible \\
FARO 52 & 0.83 & 0.9 & 0.64 & 0.76 & 0.3 & 0.61 & 0.67 & Susceptible \\
FARO 64 & 0.8 & 0.73 & 0.51 & 0.77 & 0.35 & 0.59 & 0.63 & Susceptible \\
\hline
\end{tabular}

plant while FARO 55 was the worst affected by salt treatment in this parameter, producing the lowest mean number of tillers (3.33) and the lowest Stress Response Index of 0.59 for this trait (Table 3, Figure 11).

5) Shoot Fresh Weight to Shoot Dry Weight ratio (SFW/SDW)

Data on SFW/SDW ratio showed no significant difference $(p>0.05)$ among the genotypes and also between the control and treated plants (Supplementary Table S3 \& Table S4). However, under salinity conditions FARO 44 had the maximum SFW/SDW ratio (5.54) while the minimum was recorded by FARO 55 (2.55) (Supplementary Table S3, Figure 12).

\section{6) Shoot Sodium $\left(\mathrm{Na}^{+}\right)$content}

The concentration of sodium in the shoot of the rice genotypes were significantly ( $\mathrm{p}<0.001$ ) increased by the salinity stress conditions (Supplementary Table S3 \& Table S4). Under salinity conditions the maximum $\mathrm{Na}^{+}$concentration was observed in FARO $63\left(3.36 \mu \mathrm{mol} \mathrm{Na}{ }^{+} / \mathrm{g}\right.$ DW $)$ while the minimum was in NERICA $4(1.99 \mu \mathrm{mol} \mathrm{Na}+\mathrm{g} \mathrm{DW})$ (Figure 13).

\section{7) Shoot Potassium $\left(\mathrm{K}^{+}\right)$concentration}

There was a general increase in the concentration of shoot $\mathrm{K}^{+}$under saline conditions except for NERICA 8, NERICA 2 and FARO 52 (Figure 11, Supplementary Table S3). NERICA 4 had the maximum shoot $\mathrm{K}^{+}$concentration of $2.45 \mu \mathrm{mol} \mathrm{K} / \mathrm{g} \mathrm{DW}$, while FARO 52 showed the minimum $(1.52 \mu \mathrm{mol} \mathrm{K} / \mathrm{g}$ DW) under salinity conditions (Supplementary Table S3).

\section{8) Shoot Potassium to Sodium ratio $\left(\mathrm{K}^{+} / \mathrm{Na}^{+}\right)$}

There was a general reduction in the ratio of shoot $\mathrm{K}^{+} / \mathrm{Na}^{+}$in all the rice genotypes under salt stress (Figure 10, Supplementary Table S3 \& Table S4). NERICA 4 was the least affected by the salt stress as evidenced in its highest ISRI value of 0.83 followed by FARO 44 with an ISRI of 0.67 . FARO 50 and NERICA 
2 were the worst affected by the salt stress with ISRI values of 0.3 and 0.33 respectively (Table 3 ). NERICA 2 had the minimum ratio of 0.54 , while NERICA 4 had the maximum of 1.23 under salinity stress (Supplementary Table S3, Figure 14).

\section{9) Chlorophyll Content (CC)}

Salinity stress affected the chlorophyll levels of the rice genotypes significantly $(\mathrm{p}<0.001)$ as shown in Supplementary Table S3 \& Table S4. There was a general reduction in the chlorophyll concentrations of all the rice genotypes under salt stress. RAM 137, FARO 44 and FARO 63 were least affected by salt stress with ISRI values of $0.91,0.89$ and 0.83 respectively while the worst affected was FARO 60 with ISRI value of 0.43 (Table 3) The highest level of chlorophyll accumulation among the salt stressed plants was observed in RAM 137 (2.63 $\mu \mathrm{g} / \mathrm{mg}$ FW) while the minimum was in NERICA $2(0.92 \mu \mathrm{g} / \mathrm{mg}$ FW) (Supplementary Table S3).

\section{Discussion}

\subsection{Drought Tolerance}

Eleven rice accessions which are predominantly cultivated in Nigeria were screened for drought tolerance using morpho-physiologic drought deficiency tolerance indicators previously used in various studies for the estimation of drought tolerance [17] [32] [33]. Previous reports show that other abiotic stress agents notably salt and phosphate equally lead to stunting of growth in the rice plants [18] [34] [35]. Hence relying on growth parameters such as plant height or shoot length, number of tillers and plant biomass as sole parameters for screening for drought tolerance would not be sufficient to unambiguously detect tolerance to drought. Thus, leaf rolling score and other descriptors were added.

Plant height and leaf length in the drought stressed plants were reduced compared to their control except for NERICA 5, NERICA 2 and NERICA 4 (Figure 6, Table 2). Significant reduction in both parameters for drought stressed susceptible rice plants were also reported by Farooq et al. [36] and Kumar et al. [19]. Several researchers in an attempt to explain the reduction in plant height under drought stress have attributed it to the limited cell length and reduced green leaves which act as source for carbon assimilation [17]. In the present study, all the accessions with reduced plant height also had reduced number of green leaves to further corroborate the assertion. Decreased leaf elongation under water stress is similarly caused by reduced cell expansion arising from reduction in photosynthesis. Pandey and Shukla [37] had attributed reduction in leaf area in rice under water stress to reduced photosystem 11 (PS11) activity which results in rapid declines in cell division or cell size, sometimes leading to death of the cells. Loretto et al. [38] also added that the activity of the photosynthetic electron transport chain is affected by changes in PS11 under drought conditions.

Nooden [39] reported that drought causes early senescence of the leaves 
which is supported in the present study by the increase in the number of dead leaves under drought conditions (Figure 1 and Figure 2). FARO 44 showed the highest tolerance to drought stress here by having no dead leaves from the treated plants under stress conditions, followed by NERICA 8 which showed a mean of 0.67 dead leaves per plant. FARO 52, FARO 55 and FARO 64 had the maximum number of dead leaves (2) under stress indicating their sensitivity to drought.

Tillering determines grain yield in rice plants. Reduced tiller number was reported as the major cause of yield reduction under drought stress during vegetative phase of rice growth [40]. In the present study, there was no reduction in the number of tillers for NERICA 8, NERICA 2 and FARO 44 under drought stress which further confirms their tolerance to drought. On the other hand, there was a $33 \%$ reduction in tillering for FARO 64 pointing to its susceptibility to drought stress. Similar record has been observed by Pantuwan, et al. [41] who noticed $52 \%$ to $81 \%$ decrease in number of tillers in rice plants under drought stress. Tiller abortion has been noticed in previous reports [17].

Significant variation was observed in Leaf rolling score (LRS) among the genotypes under drought stress (Table 2). LRS has been identified as a standard parameter for estimation of drought stress [20] [42] [43] [44]. FARO 44 and NERICA 8 had the smallest LRS of 1.33 each (Figure 4), which indicates their resistance to drought stress conditions. On the other hand, FARO 64 had the highest LRS score of 4.33 which indicates its susceptibility to drought conditions. Leaf rolling is caused by loss of turgor and poor osmotic adjustment in rice plants [43]. It is a defensive mechanism for reducing net radiation load on the leaf [21].

For water retention, FARO 44 had the best performance which could be seen as a confirmation of its drought tolerance quality (Figure 7). Water retention ability indicates the degree of hydration in cells and tissues which is crucial for optimization of growth processes in plants. The ability to retain higher relative water content under drought condition is a tolerance mechanism for water scarcity in rice [45]. When the means of the Individual Stress Response Indices for all the parameters were taken into consideration, NERICA 8, NERICA 5, NERICA 2 and FARO 44 were clearly tolerant to drought stress which further confirms the tolerance report on FARO 44 by Afiukwa et al. [1].

\subsection{Salinity Tolerance}

In this study, tolerance to salinity stress was estimated using morpho-physiologic traits in the eleven rice accessions. Morphological parameters such as shoot dry weight (SDW), shoot fresh weight (SFW), and tillering are reported to be significantly correlated with salt tolerance at different stages of growth and can be used as indicators for estimation of salt tolerance [22]. In this study, salinity caused reduction in plant height in many of the rice accessions (to different levels) compared with their controls which is consistent with reports by Chinnusamy et al. [23]. There was, however, no reduction in the plant height of RAM 
137 and FARO 44 which confirms the high tolerance level of these 2 accessions to salinity stress. FARO 64 with $37 \%$ reduction is susceptible to salinity stress.

The number of tillers per plant is an important yield parameter under salinity because it determines the number of grain-bearing panicles [24] of the rice plants which eventually reflects on the total yield of the plant. Salinity caused reduction in the number of tillers per plant with maximum reduction (70\%) observed in FARO 55 while RAM 137 had the minimum reduction (4\%), (Figure 15). This result also indicates the tolerance of RAM 137 to salinity conditions and the sensitivity of FARO 55. The finding is in agreement with Zeng and Shannon [25] and Tanveer-Ul-Haq et al. [24] who also observed a significant reduction in tillering in rice plants exposed to salt. In the present study, it was observed that salinity caused a significant reduction in SFW and SDW. According to Munns et al. [46], this reduction in biomass could be attributed to decreased water potential of the rooting medium and growth inhibition caused by the salinity stress. Ashraf and Sawar [47] further attributed the reduction in plant biomass under salt stress to imbalances in the uptake of mineral nutrients due to competition with the excess influx of $\mathrm{Na}^{+}$. In this study, the lowest reduction in SFW was noticed in FARO 44 (6.5\%) while the maximum reduction was observed in FARO 55 (67\%).

$\mathrm{Na}^{+}$increased significantly under salinity conditions in all the accessions. FARO 44, RAM 137 and NERICA 4 had the least accumulation of $\mathrm{Na}^{+}$under salinity conditions which indicates their good tolerance level to salt stress, while FARO 55, FARO 64 and FARO 63 had the highest accumulation of $\mathrm{Na}^{+}$signifying their sensitivity to salinity stress. Salt tolerant varieties generally maintain lower concentrations of $\mathrm{Na}^{+}$in their shoot than those of salt sensitive varieties under excess salt conditions [48]. Indeed, Munns and Tester [12] noted that the ability of crops to maintain low cytosolic levels of $\mathrm{Na}^{+}$in leaves is taken to be one of the major determining factors for salt tolerance. Higher concentrations of $\mathrm{Na}^{+}$ are harmful to plant growth and could be responsible for reduction in plant biomass [24]. The relationship between $\mathrm{Na}^{+}$and $\mathrm{K}^{+}$concentration in plants follows that a good supply of $\mathrm{K}^{+}$to plants could reduce the rate of injury as a result of high $\mathrm{Na}^{+}$concentration under salinity conditions [24]. A positive relationship between high $\mathrm{K}^{+} / \mathrm{Na}^{+}$and salinity tolerance has been established by some workers [26].

Total leaf chlorophyll content was significantly reduced under salinity conditions. RAM 137 had the least (10\%) reduction in leaf chlorophyll under salinity conditions when compared with the total chlorophyll content of the control plants which points to its good tolerance to salinity stress. Reduction in chlorophyll content under salinity stress has been reported by Ali et al. [27], who found out that the deleterious effects of toxic amounts of $\mathrm{NaCl}$ and unbalanced nutrient uptake by plants under salinity stress could cause a significant decrease in photosynthesis.

When the means of the Stress Response Indices for all the parameters were taken into consideration, RAM 137 and FARO 44 were clearly tolerant to salt 
stress, FARO 61, FARO 63, NERICA 8, NERICA 4, and FARO 60 were moderately tolerant while FARO 64, FARO 52, NERICA 2 and FARO 55 were sensitive (Table 3). This result is in agreement with reports by Uyoh et al. [29] and Kargbo et al. [49] on the status of FARO 61. Most of the varieties used in these studies were different. Also, the parameters analyzed were different except for shoot length and biomass which may also account for the differences observed.

It is clear from the results presented here that plant responses to drought and salinity involve changes in numerous parameters with no single accession topping the chart in all the traits. It signifies that these plants use several pathways to ensure survival. The final classification of the degree of tolerance in this study was therefore based on the mean of the Individual Stress Response Indices from all the parameters estimated.

\section{Conclusion}

The present study evaluated the performance of eleven rice genotypes using morphological and physiological growth parameters, under induced drought and salinity conditions. Generally, significant differences were obtained ( $\mathrm{p}<$ 0.05) for most of the traits among the accessions studied (Supplementary Tables S1-S4), indicating the presence of exploitable genetic variation in these accessions. Of the genotypes evaluated, four (FARO 44, NERICA 2, NERICA 8 and NERICA 5) were identified as tolerant, two (NERICA 4 and FARO 57) as moderately tolerant, while the rest were found to be sensitive to drought. Equally, two varieties (FARO 44 and RAM 137) stood out in the salinity screening as tolerant varieties, five were moderately tolerant while four (FARO 64, FARO 52, NERICA 2 and FARO 55) were clearly susceptible. It is interesting to note that FARO 44 is the only one from the 11 accessions screened that is tolerant to both drought and salinity. The identified drought and salinity tolerant rice genotypes from this study can be recommended as genetic sources for future breeding programs for drought and salinity resistance in rice.

\section{Conflicts of Interest}

The authors declare no conflicts of interest regarding the publication of this paper.

\section{References}

[1] Afiukwa, C.A., Faluyi, J.O., Atkinson, C.J., Ubi, B.E., Igwe, D.O. and Akinwale, R.O. (2016) Screening of Some Rice Varieties and Landraces Cultivated in Nigeria for Drought Tolerance Based on Phenotypic Traits and Their Association with SSR Polymorphism. African Journal of Agricultural Research, 11, 2599-2615. https://doi.org/10.5897/AJAR2016.11239

[2] Food and Agriculture Organization (2017) The Future of Food and Agriculture-Trends and Challenges. Rome, Italy.

[3] Global Rice Science Partnership (2013) Rice Almanac. 4th Edition, International Rice Research Institute, Los Baños. 
[4] Thakur, P., Kumar, S., Malik, J.A., Berger, J.D. and Nayyar, H. (2010) Cold Stress Effects on Reproductive Development in Grain Crops: An Overview. Journal of Environmental and Experimental Botany, 67, 429-443. https://doi.org/10.1016/j.envexpbot.2009.09.004

[5] Serraj, R., McNally, K.L., Slamet-Loedin, I., Kohli, A., Haefele, S.M., Atlin, G., Kumar, A. (2011) Drought Resistance Improvement in Rice: An Integrated Genetic and Resource Management Strategy. Plant Production Science, 14, 1-14.

https://doi.org/10.1626/pps.14.1

[6] Ahmad, M.S., Wu, B.R., Wang, H.Q. and Kang, D.M. (2020). Field Screening of Rice Germplasm (Oryza sativa L. ssp. japonica) Based on Days to Flowering for Drought Escape. Plants, 9, 609. https://doi.org/10.3390/plants9050609

[7] Srividhya, A, Vemireddy, L.R, Sridhar, S, Jayaprada, M., Ramanarao, P.V., Hariprasad, A.S., Reddy, H.K., Anuradha, G. and Siddiq, E. (2011) Molecular Mapping of QTLs for Yield and Its Components under Two Water Supply Conditions in Rice (Oryza sativa L.). Journal of Crop Science and Biotechnology, 14, 45-56. https://doi.org/10.1007/s12892-010-0023-x

[8] Saini, H.S. and Westgate, M.E. (1999). Reproductive Development in Grain Crops during Drought. Advances in Agronomy, 68, 59-96.

https://doi.org/10.1016/S0065-2113(08)60843-3

[9] Mustać, I., Filipović, V., Filipović, L., Ondrašek, G. and DragutinPetošić. (2019). Agricultural Management Strategies for Countering Drought Conditions in Eastern Croatia Drought-Detection and Solutions, intechopen.com.

[10] Atkinson, N.J. and Urwin, P.E. (2012) The Interaction of Plant Biotic and Abiotic Stresses: From Genes to the Field. Journal of Experimental Botany, 63, 3523-3543. https://doi.org/10.1093/jxb/ers100

[11] Bargaz, A., Zaman-Allah, M., Farissi, M., Lazali, M., Drevon, J., Maougal, R.T. and Georg, C. (2015) Physiological and Molecular Aspects of Tolerance to Environmental Constraints in Grain and Forage Legumes. International Journal of Molecular Science, 16, 18976-19008. https://doi.org/10.3390/ijms160818976

[12] Munns, R. and Tester, M. (2008) Mechanisms of Salinity Tolerance. Annual Review of Plant Biology, 59, 651-681. https://doi.org/10.1146/annurev.arplant.59.032607.092911

[13] Xiong, L.M. and Zhu, J.K. (2001) Abiotic Stress Signal Transduction in Plants: Molecular and Genetic Perspectives. Physiologia Plantarum, 112, 152-166.

[14] Kumar, K., Kumar, M., Kim, S.R., Ryu, H. and Cho, Y.G. (2013) Insights into Genomics of Salt Stress Response in Rice. The Rice Journal, 6, Article No. 27. https://doi.org/10.1186/1939-8433-6-27

[15] Wang, W., Vinocur, B. and Altman, A. (2003) Plant Responses to Drought, Salinity and Extreme Temperatures: Towards Genetic Engineering for Stress Tolerance. Planta, 218, 1-14. https://doi.org/10.1007/s00425-003-1105-5

[16] Lone, A.A., Jumaa, S.H., Wijewardana, C., Taduri, S., Redona, E.D. and Reddy, K.R. (2019). Drought Stress Tolerance Screening of Elite American Breeding Rice Genotypes Using Low-Cost Pre-Fabricated Mini-Hoop Modules. Agronomy, 9, 199. https://doi.org/10.3390/agronomy9040199

[17] Singh, B., Reddy, K.R., Redona, E.D. and Walker, T. (2017) Screening of Rice Cultivars for Morpho-Physiological Responses to Early-Season Soil Moisture Stress. Rice Science, 24, 322-335. https://doi.org/10.1016/j.rsci.2017.10.001

[18] Uyoh, E.A., Ntui, V.O., Umego, C., Ita, E.E. and Opara, C. (2019) Morphological and Molecular Screening of Rice Accessions for Salt Tolerance. African Journal of 
Biotechnology, 18, 612-621. https://doi.org/10.5897/AJB2019.16801

[19] Kumar, S., Dwivedi, S.K., Haris, A.A., Prakash, V., Mondal, S. and Singh, S.K. (2015) Screening and Identification of Rice Genotypes for Drought Tolerance at Reproductive Stage under Rainfed Lowland Conditions. Journal of Agrisearch, 2, 105-111.

[20] Lilly, J.M and Fukai, S. (1994) Effect of Timing and Severity of Water Deficit on Four Diverse Rice Cultivars. 1. Phonological Development, Crop Growth and Grain Yield. Field Crops Research, 37, 225-235. https://doi.org/10.1016/0378-4290(94)90101-5

[21] Swapna, S. and Shylaraj, K.S. (2017) Screening for Osmotic Stress Responses in Rice Varieties under Drought Condition. Rice Science, 24, 253-263.

https://doi.org/10.1016/j.rsci.2017.04.004

[22] Shereen, A., Shirazi, M.U., Khan, M.A. and Mumtaz, S. (2015) Salt Tolerance Potential of Upland and Lowland Rice in Physiological Perspectives. Pakistan Journal of Botany, 47, 2055-2061.

[23] Chinnusamy, V., Jagendorf, A. and Zhu, J.K. (2005) Understanding and Improving Salt Tolerance in Plants. Journal of Crop Science, 45, 437-448.

[24] Tanveer, U.H., Javaid, A., Shafqat, N. and Rashid, A. (2009) Morpho-Physiological Response of Rice (Oryza sativa L.) Varieties to Salinity Stress. Pakistani Journal of Botany, 41, 2943-2956.

[25] Zeng, L.H. and Shannon, M.C. (2000) Salinity Effects on Seedling Growth and Yield Components of Rice. Crop Science, 40, 996-1003. https://doi.org/10.2135/cropsci2000.404996x

[26] Gregorio, G.B. and Senadhira, D. (1993) Genetic Analysis of Salinity Tolerance in Rice (Oryza sativa L.). Theoretical and Applied Genetics, 86, 333-338. https://doi.org/10.1007/BF00222098

[27] Ali, N., Yeasmin, L., Gantait, S., Goswami, R. and Chakraborty, S. (2014) Screening of Rice Landraces for Salinity Tolerance at Seedling Stage through Morphological and Molecular Markers. Physiology and Molecular Biology of Plants, 20, 411-423. https://doi.org/10.1007/s12298-014-0250-6

[28] Zhang, Q., Li, J.J., Zhang, W.J., Yan, S.N., Wang, R., Zhao, J.F., Li, Y., Qi, Z., Sun, Z. and Zhu, Z.G. (2012) The Putative Auxin Efflux Carrier OsPIN3t is Involved in the Drought Stress Response and Drought Tolerance. The Plant Journal, 2, 805-816. https://doi.org/10.1111/j.1365-313X.2012.05121.x

[29] O’Toole, J.C and Cruz, R.T. (1979) Leaf Rolling and Transpiration. Plant Science Letters, 16, 111-114. https://doi.org/10.1016/0304-4211(79)90015-4

[30] Hiscox, J.D. and Israelstam, J.F. (1979) A Method for the Extraction of Chlorophyll from Leaf Tissue without Maceration. Canadian Journal of Botany, 57, 1332-1334. https://doi.org/10.1139/b79-163

[31] Roy, S.J., Huang, W., Wang, X.J., Evrard, A., Schmoeckel, S.M., Zafar, Z.U. and Tester, M. (2013) A Novel Protein Kinase Involved in $\mathrm{Na}^{+}$Exclusion Revealed from Positional Cloning. Plant, Cell and Environment, 36, 553-568.

https://doi.org/10.1111/j.1365-3040.2012.02595.x

[32] Islam, R., Mukherjee, A. and Hossin, M. (2012) Effect of Osmopriming on Rice Seed Germination and Seedling Growth. Journal of the Bangladesh Agriculture University, 10, 15-20. http://dx.doi.org/10.3329/jbau.v10i1.12013

[33] Todaka, D., Shinozaki, K. and Yamaguchi-Shinozaki, K. (2015) Recent Advances in the Dissection of Drought-Stress Regulatory Networks and Strategies for Develop- 
ment of Drought-Tolerant Transgenic Rice Plants. Frontiers in Plant Science, 6, 84-104. https://doi.org/10.3389/fpls.2015.00084

[34] Frydenvang, J., van Maarschalkerweerd, M. and Carstensen, A. (2015) Sensitive Detection of Phosphorus Deficiency in Plants Using Chlorophyll a Fluorescence. Journal of Plant Physiology, 169, 353-361. https://doi.org/10.1104/pp.15.00823

[35] Aluwihare, Y.C., Ishan, M., Chamikara, M.D.M., Weebadde, C.K., Sirisena, D.N., Samarasinghe, W.L.G. and Sooriyapathirana, S.D.S.S. (2016) Characterization and Selection of Phosphorus Deficiency Tolerant Rice Genotypes in Sri Lanka. Rice Science, 23, 184-195. https://doi.org/10.1016/j.rsci.2015.10.001

[36] Farooq, M., Kobayashi, N., Ito, O., Wahid, A. and Serraj, R. (2010) Broader Leaves Result in Better Performance of Indica Rice under Drought Stress. Journal of Plant Physiology, 167, 1066-1075. https://doi.org/10.1016/j.jplph.2010.03.003

[37] Pandey, V. and Shukla, A. (2015) Acclimation and Tolerance Strategies of Rice under Drought Stress. Rice Science, 22, 147-161. https://doi.org/10.1016/j.rsci.2015.04.001

[38] Loreto, F., Tricoli, D. and Di, M.G. (1995) On the Relationship between Electron Transport Rate and Photosynthesis in Leaves of the $\mathrm{C}_{4}$ Plant Sorghum bicolor Exposed to Water Stress, Temperature Changes and Carbon Metabolism Inhibition. Australian Journal of Plant Physiology, 22, 885-892.

https://doi.org/10.1071/PP9950885

[39] Nooden, L.D. (1988). The Phenomenon of Senescence and Aging. In: Noodén, L.D. AND and Leopold, A.C., Eds., Senescence and Aging in Plants, Academic Press, San Diego. https://doi.org/10.1016/B978-0-12-520920-5.50007-9

[40] Rahman, M.T., Islam, M.T. and Islam, M.O. (2002) Effect of Water Stress at Different Growth Stages on Yield and Yield Contributing Characters of Transplanted Aman Rice. Pakistan Journal of Biological Sciences, 5, 169-172. https://dx.doi.org/10.3923/pjbs.2002.169.172

[41] Pantuwan, G., Fukai, S., Copper, M., Rajatasereekul, S. and O’Toole, J.C. (2002). Yield Response of Rice (Oryza sativa L.) Genotypes to Drought under Rainfed Lowlands. Field Crops Research, 73, 169-180.

[42] O’Toole, J.C. and Cruz, R.T. (1980) Response of Leaf Water Potential, Stomatal Resistance and Leaf Rolling to Water Stress. Plant Physiology, 65, 428-432. https://doi.org/10.1104/pp.65.3.428

[43] Hsiao, T.C., O’Toole, J.C., Yambao, E.B and Turner, N.C. (1984) Influence of Osmotic Adjustment on Leaf Rolling and Tissue Death in Rice (Oryza sativa L.). Plant Physiology, 75, 338-341. https://doi.org/10.1104/pp.75.2.338

[44] Ehanayake, I.J., O’Toole, D.J. and Garrity, D. (1985) Inheritance of Root Characters and Their Relations to Drought Resistance in Rice. Crop Science, 25, 927-933. https://doi.org/10.2135/cropsci1985.0011183X002500060007x

[45] O’Toole, J.C. and Moya, T.B. (1978) Genotypic Variation in Maintenance of Leaf Water Potential in Rice. Crop Science, 18, 873-876. https://doi.org/10.2135/cropsci1978.0011183X001800050050x

[46] Munns, R., Schachtman, D. and Condon, A. (1995) The Significance of a Two-Phase Growth Response to Salinity in Wheat and Barley. Functional Plant Biology, 22, 561-569. https://doi.org/10.1071/PP9950561

[47] Ashraf, M.Y. and Sarwar, G. (2002) Salt Tolerance Potential in Some Members of Brassicaceae Physiological Studies on Water Relations and Mineral Contents. In: Ahmad, K.R. and Malik, A., Eds., Prospects for Saline Agriculture, Springer, Dordrecht, 237-245. https://doi.org/10.1007/978-94-017-0067-2_26 
[48] Lutts, S. and Guerrir, G. (1995) Peroxidase Activities of Two Rice Cultivars Differing in Salinity Tolerance as Affected by Proline and NaCl. Biologia Plantarum, 37, 577-586. https://doi.org/10.1007/BF02908842

[49] Kargbo, S.S., Showemimo, F.A., Porbeni, J.B.O. and Akintokun, P.O. (2019) Response of Rice Genotypes to Salinity under Hydroponic Conditions. Agro-Science, 18, 11-18. https://doi.org/10.4314/as.v18i3.3 


\section{Supplementary}

Table S1. Means of morphometric data of drought stressed and non-stressed rice plants.

\begin{tabular}{cccccccccccccc}
\hline Parameters & \multicolumn{2}{c}{ Dead leaves } & \multicolumn{2}{c}{ Green leaves } & \multicolumn{2}{c}{ Leaf length } & \multicolumn{2}{c}{ LRS } & \multicolumn{2}{c}{ Tillers } & & PH \\
\hline Variety & A & B & A & B & A & B & A & B & A & B & A & B \\
\hline FARO 52 & $0.67 \mathrm{a}$ & $2.00 \mathrm{a}$ & $6.00 \mathrm{bc}$ & $4.00 \mathrm{bc}$ & $35.67 \mathrm{bc}$ & $32.33 \mathrm{bcd}$ & $1.00 \mathrm{a}$ & $4.00 \mathrm{a}$ & $4.33 \mathrm{~b}$ & $3.33 \mathrm{bcd}$ & $51.33 \mathrm{~cd}$ & $47.00 \mathrm{~cd}$ \\
FARO 44 & $0.00 \mathrm{~b}$ & $0.00 \mathrm{~d}$ & $7.67 \mathrm{a}$ & $6.33 \mathrm{a}$ & $42.33 \mathrm{a}$ & $33.00 \mathrm{abcd}$ & $1.00 \mathrm{a}$ & $1.33 \mathrm{~d}$ & $5.67 \mathrm{a}$ & $5.00 \mathrm{a}$ & $58.33 \mathrm{ab}$ & $47.67 \mathrm{bcd}$ \\
FARO 61 & $0.00 \mathrm{~b}$ & $1.00 \mathrm{bc}$ & $7.00 \mathrm{ab}$ & $4.00 \mathrm{bc}$ & $37.67 \mathrm{~b}$ & $29.67 \mathrm{~d}$ & $1.00 \mathrm{a}$ & $3.00 \mathrm{~b}$ & $6.00 \mathrm{a}$ & $4.00 \mathrm{~b}$ & $55.00 \mathrm{bc}$ & $48.00 \mathrm{bcd}$ \\
NERICA 5 & $0.00 \mathrm{~b}$ & $1.00 \mathrm{bc}$ & $4.33 \mathrm{~d}$ & $4.00 \mathrm{bc}$ & $24.33 \mathrm{~d}$ & $32.00 \mathrm{bcd}$ & $1.00 \mathrm{a}$ & $2.33 \mathrm{c}$ & $3.33 \mathrm{~cd}$ & $3.00 \mathrm{~cd}$ & $38.33 \mathrm{e}$ & $45.33 \mathrm{de}$ \\
NERICA 8 & $0.33 \mathrm{ab}$ & $0.67 \mathrm{c}$ & $4.33 \mathrm{~d}$ & $5.00 \mathrm{~b}$ & $39.00 \mathrm{ab}$ & $37.33 \mathrm{a}$ & $1.00 \mathrm{a}$ & $1.33 \mathrm{~d}$ & $3.67 \mathrm{bcd}$ & $4.00 \mathrm{~b}$ & $61.33 \mathrm{a}$ & $58.33 \mathrm{a}$ \\
FARO 64 & $0.33 \mathrm{ab}$ & $2.00 \mathrm{a}$ & $5.00 \mathrm{~cd}$ & $3.67 \mathrm{c}$ & $32.00 \mathrm{c}$ & $30.00 \mathrm{~d}$ & $1.00 \mathrm{a}$ & $4.33 \mathrm{a}$ & $4.00 \mathrm{bc}$ & $3.00 \mathrm{~cd}$ & $45.67 \mathrm{~d}$ & $45.00 \mathrm{de}$ \\
NERICA 4 & $0.33 \mathrm{ab}$ & $1.00 \mathrm{bc}$ & $5.33 \mathrm{~cd}$ & $4.67 \mathrm{bc}$ & $35.67 \mathrm{bc}$ & $35.67 \mathrm{ab}$ & $1.00 \mathrm{a}$ & $2.67 \mathrm{bc}$ & $3.67 \mathrm{bcd}$ & $3.00 \mathrm{~cd}$ & $46.67 \mathrm{~d}$ & $51.33 \mathrm{bc}$ \\
FARO 55 & $0.33 \mathrm{ab}$ & $2.00 \mathrm{a}$ & $5.00 \mathrm{~cd}$ & $3.67 \mathrm{c}$ & $31.33 \mathrm{c}$ & $30.67 \mathrm{~cd}$ & $1.00 \mathrm{a}$ & $4.00 \mathrm{a}$ & $3.33 \mathrm{~cd}$ & $2.67 \mathrm{~d}$ & $48.67 \mathrm{~d}$ & $40.33 \mathrm{e}$ \\
NERICA 2 & $0.33 \mathrm{ab}$ & $1.33 \mathrm{~b}$ & $4.33 \mathrm{~d}$ & $4.67 \mathrm{bc}$ & $25.33 \mathrm{~d}$ & $32.33 \mathrm{bcd}$ & $1.00 \mathrm{a}$ & $2.33 \mathrm{c}$ & $3.00 \mathrm{~d}$ & $3.00 \mathrm{~cd}$ & $38.67 \mathrm{e}$ & $48.33 \mathrm{bcd}$ \\
FARO 57 & $0.00 \mathrm{~b}$ & $1.00 \mathrm{bc}$ & $7.00 \mathrm{ab}$ & $4.67 \mathrm{bc}$ & $38.33 \mathrm{ab}$ & $30.33 \mathrm{~cd}$ & $1.00 \mathrm{a}$ & $2.00 \mathrm{c}$ & $4.00 \mathrm{bc}$ & $3.67 \mathrm{bc}$ & $56.00 \mathrm{abc}$ & $49.33 \mathrm{bcd}$ \\
FARO 63 & $0.33 \mathrm{ab}$ & $1.33 \mathrm{~b}$ & $5.00 \mathrm{~cd}$ & $4.33 \mathrm{bc}$ & $38.33 \mathrm{ab}$ & $34.33 \mathrm{ab}$ & $1.00 \mathrm{a}$ & $4.00 \mathrm{a}$ & $4.00 \mathrm{bc}$ & $3.67 \mathrm{bc}$ & $60.00 \mathrm{ab}$ & $53.33 \mathrm{ab}$ \\
LSD & 0.64 & & 1.19 & & 4.44 & & 0.48 & & 0.883 & & 5.88 &
\end{tabular}

A = control plants under constant irrigation; $\mathbf{B}=$ plants under drought stress without any irrigation for two weeks. Means denoted with the same lower-case letter within each column are not significantly different at $\mathrm{p}>0.05$.

Table S2. Analysis of variance results on the morphometric parameters in 11 rice genotypes under drought stress.

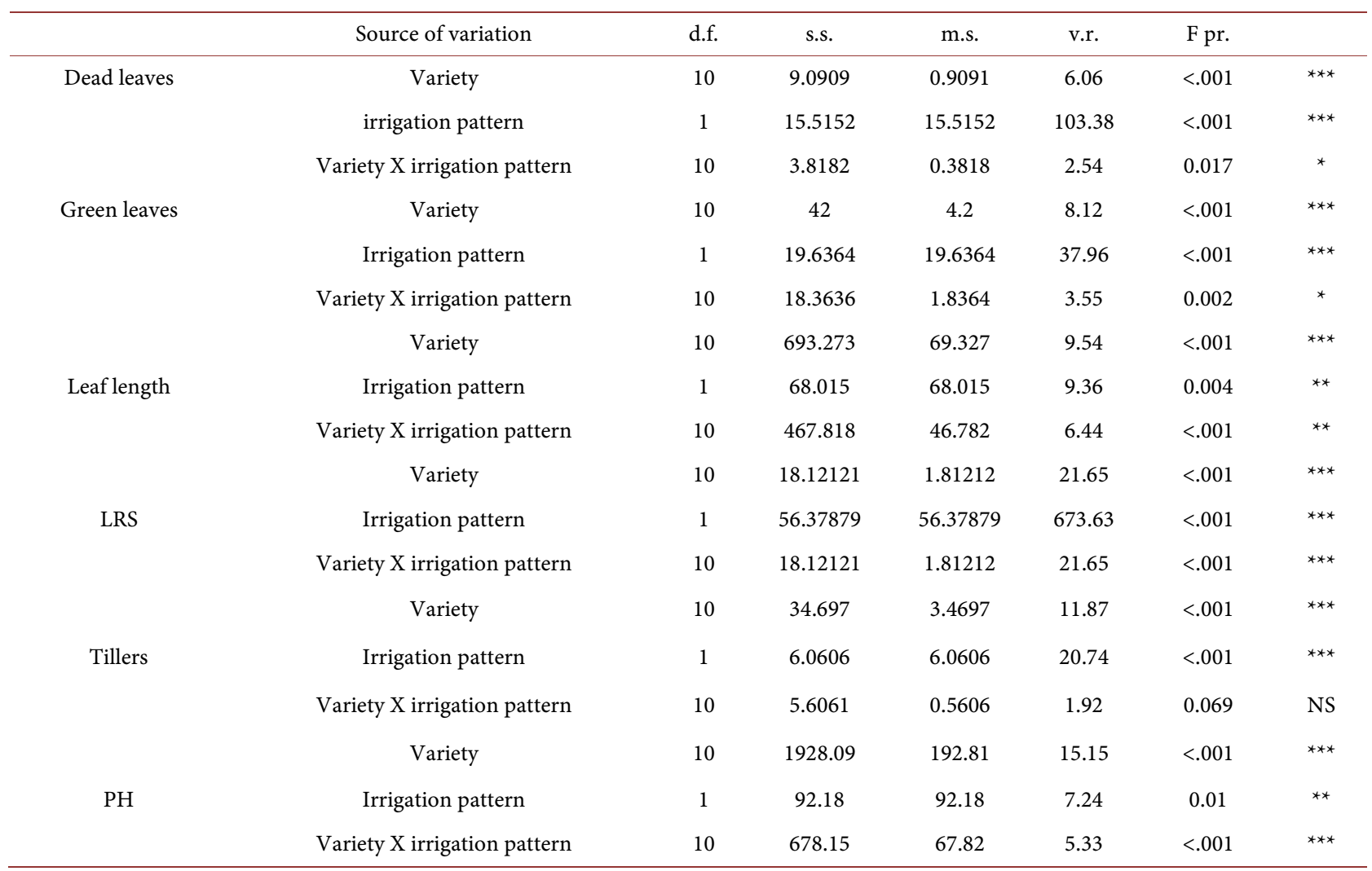

${ }^{*}=$ significant at $\mathrm{p} \leq 0.05,{ }^{* *}=$ significant at $\mathrm{p} \leq 0.01,{ }^{* *}$ significant at $\mathrm{p} \leq 0.001 . \mathrm{N} . \mathrm{S}=$ not significant $\mathrm{PH}=$ plant height, LRS $=$ leaf rolling score. 
Table S3. Means of morpho-physiologic data of salt stressed rice plants.

\begin{tabular}{|c|c|c|c|c|c|c|c|c|c|c|}
\hline \multirow{2}{*}{$\begin{array}{l}\text { Parameters } \\
\text { Accessions }\end{array}$} & \multicolumn{2}{|c|}{ Tillers } & \multicolumn{2}{|c|}{$\mathrm{PH}(\mathrm{cm})$} & \multicolumn{2}{|c|}{ SDW (g) } & \multicolumn{2}{|c|}{ SFW (g) } & \multicolumn{2}{|c|}{ SFW/SDW } \\
\hline & $0 \mathrm{mM}$ & $75 \mathrm{mM}$ & $0 \mathrm{mM}$ & $75 \mathrm{mM}$ & $0 \mathrm{mM}$ & $75 \mathrm{mM}$ & $0 \mathrm{mM}$ & $75 \mathrm{mM}$ & $0 \mathrm{mM}$ & $75 \mathrm{mM}$ \\
\hline RAM 137 & $14.67 \mathrm{a}$ & $14.00 \mathrm{a}$ & $108.33 a$ & $107.33 a$ & $2.11 \mathrm{de}$ & $1.87 \mathrm{abc}$ & $8.33 \mathrm{~cd}$ & $6.39 \mathrm{~cd}$ & 4.11 & 3.43 \\
\hline FARO 44 & $11.00 \mathrm{~b}$ & $10.33 b$ & $101.67 \mathrm{ab}$ & $100.67 \mathrm{ab}$ & $3.18 \mathrm{bc}$ & $2.66 \mathrm{a}$ & $14.08 \mathrm{a}$ & $13.74 \mathrm{a}$ & 4.72 & 5.54 \\
\hline FARO 61 & $9.67 b c$ & $7.33 \mathrm{~cd}$ & $98.00 \mathrm{ab}$ & $92.33 b$ & $2.71 \mathrm{~cd}$ & $2.09 \mathrm{abc}$ & $7.77 \mathrm{~cd}$ & $7.4 \mathrm{bc}$ & 2.92 & 3.55 \\
\hline NERICA 8 & 7.33de & 5.33defg & $99.33 \mathrm{ab}$ & $94.67 \mathrm{~b}$ & $2.07 \mathrm{de}$ & $1.96 a b c$ & $8.11 \mathrm{~cd}$ & $7.07 \mathrm{bc}$ & 3.97 & 3.66 \\
\hline NERICA 4 & 7.33de & $4.67 \mathrm{fg}$ & $102.67 \mathrm{ab}$ & $89.33 b$ & $3.52 \mathrm{abc}$ & $2.09 \mathrm{abc}$ & $10.81 \mathrm{~b}$ & $7.92 \mathrm{bc}$ & 3.07 & 3.80 \\
\hline FARO 55 & $5.67 \mathrm{e}$ & $3.33 \mathrm{~g}$ & $94.00 \mathrm{~b}$ & $90.67 b$ & $1.79 \mathrm{e}$ & $1.38 \mathrm{c}$ & $7.57 \mathrm{~d}$ & $4.52 \mathrm{~d}$ & 5.85 & 2.55 \\
\hline FARO 64 & $8.33 \mathrm{~cd}$ & $6.67 \mathrm{cdef}$ & $91.67 \mathrm{~b}$ & $66.67 \mathrm{c}$ & $2.88 \mathrm{bcd}$ & $1.48 \mathrm{bc}$ & $7.41 \mathrm{~d}$ & $5.72 \mathrm{~cd}$ & 3.01 & 3.98 \\
\hline NERICA 2 & $9.00 \mathrm{~cd}$ & $6.33 \mathrm{def}$ & $100.33 \mathrm{ab}$ & $95.67 \mathrm{ab}$ & $1.75 \mathrm{e}$ & $1.40 \mathrm{c}$ & $8.2 \mathrm{~cd}$ & $6.22 \mathrm{~cd}$ & 4.64 & 4.48 \\
\hline FARO 63 & $9.67 \mathrm{bc}$ & $8.67 \mathrm{bc}$ & $102.33 \mathrm{ab}$ & $88.00 \mathrm{~b}$ & $4.12 \mathrm{a}$ & $2.58 \mathrm{a}$ & $15.24 \mathrm{a}$ & $12.01 \mathrm{a}$ & 3.72 & 5.02 \\
\hline FARO 60 & 7.33de & 7.00cde & $110.00 \mathrm{a}$ & $98.00 \mathrm{ab}$ & $3.70 \mathrm{ab}$ & $2.47 \mathrm{a}$ & $13.24 \mathrm{a}$ & $9.43 b$ & 3.57 & 3.96 \\
\hline FARO 52 & $6.00 \mathrm{e}$ & $5.00 \mathrm{efg}$ & $100.00 \mathrm{ab}$ & $90.33 b$ & $3.62 \mathrm{ab}$ & $2.32 \mathrm{ab}$ & $10.11 b c$ & $7.64 b c$ & 2.83 & 3.60 \\
\hline LSD & 2.3 & & 12.83 & & 0.857 & & 2.41 & & NS & \\
\hline
\end{tabular}

\begin{tabular}{|c|c|c|c|c|c|c|c|c|c|c|}
\hline \multirow{2}{*}{$\begin{array}{l}\text { Parameter } \\
\text { Accession }\end{array}$} & \multicolumn{2}{|c|}{$\mathrm{K} / \mathrm{Na}$} & \multicolumn{2}{|c|}{ Chlorophyll } & \multicolumn{2}{|c|}{ Shoot $\mathrm{K}^{+} \mu \mathrm{mol}$} & \multicolumn{2}{|c|}{ Shoot $\mathrm{Na}^{+} \mu \mathrm{mol}$} & \multicolumn{2}{|c|}{ Relative Water content $\%$} \\
\hline & $0 \mathrm{mM}$ & $75 \mathrm{mM}$ & $0 \mathrm{mM}$ & $75 \mathrm{mM}$ & $0 \mathrm{mM}$ & $75 \mathrm{mM}$ & $0 \mathrm{mM}$ & $75 \mathrm{mM}$ & $0 \mathrm{mM}$ & $75 \mathrm{mM}$ \\
\hline RAM 137 & 1.57 & 0.83 & $2.60 \mathrm{~b}$ & $2.36 \mathrm{a}$ & $1.37 \mathrm{cde}$ & $1.92 \mathrm{bc}$ & $0.87 \mathrm{a}$ & $2.30 \mathrm{cde}$ & 74.67 & 70.74 \\
\hline FARO 44 & 1.45 & 0.97 & $2.00 \mathrm{~cd}$ & $1.78 \mathrm{bc}$ & $1.40 \mathrm{bcde}$ & $1.99 \mathrm{~b}$ & $0.96 \mathrm{a}$ & $2.06 \mathrm{de}$ & 77.41 & 80.64 \\
\hline FARO 61 & 1.53 & 0.93 & $2.26 \mathrm{bc}$ & $1.61 \mathrm{~cd}$ & $1.55 \mathrm{bcd}$ & $2.19 \mathrm{ab}$ & $1.01 \mathrm{a}$ & $2.35 \mathrm{cde}$ & 65.1 & 71.76 \\
\hline NERICA 8 & 1.89 & 0.71 & $2.33 b c$ & $1.46 \mathrm{~cd}$ & $2.17 \mathrm{a}$ & $1.60 \mathrm{cde}$ & $1.15 \mathrm{a}$ & $2.27 \mathrm{cde}$ & 74.48 & 72.28 \\
\hline NERICA 4 & 1.48 & 1.23 & $2.48 \mathrm{~b}$ & $1.59 \mathrm{~cd}$ & $1.27 \mathrm{de}$ & $2.45 a$ & $0.86 \mathrm{a}$ & $1.99 \mathrm{e}$ & 67.44 & 73.61 \\
\hline FARO 55 & 1.21 & 0.67 & $3.06 \mathrm{a}$ & $2.07 \mathrm{ab}$ & $1.37 \mathrm{cde}$ & $2.03 \mathrm{~b}$ & $1.13 \mathrm{a}$ & $3.01 \mathrm{ab}$ & 76.35 & 69.47 \\
\hline FARO 64 & 1.91 & 0.67 & $2.03 c$ & $1.21 \mathrm{de}$ & $1.72 \mathrm{bc}$ & $1.98 \mathrm{bc}$ & $0.90 \mathrm{a}$ & $2.97 \mathrm{ab}$ & 61.13 & 74.13 \\
\hline NERICA 2 & 1.63 & 0.54 & $1.99 \mathrm{~cd}$ & $0.92 \mathrm{e}$ & $1.77 \mathrm{~b}$ & $1.44 \mathrm{e}$ & $1.08 \mathrm{a}$ & $2.67 \mathrm{bc}$ & 78.66 & 77.49 \\
\hline FARO 63 & 1.07 & 0.56 & $1.57 \mathrm{~d}$ & $1.31 \mathrm{de}$ & $1.24 \mathrm{de}$ & $1.88 \mathrm{bcd}$ & $1.16 \mathrm{a}$ & $3.36 \mathrm{a}$ & 72.97 & 78.52 \\
\hline FARO 60 & 1.42 & 0.83 & $3.21 \mathrm{a}$ & $1.38 \mathrm{~cd}$ & $1.11 \mathrm{e}$ & $1.98 \mathrm{bc}$ & $0.78 \mathrm{a}$ & $2.40 \mathrm{cde}$ & 72.05 & 73.80 \\
\hline FARO 52 & 2.06 & 0.63 & $2.33 b c$ & $1.41 \mathrm{~cd}$ & $1.67 \mathrm{bc}$ & $1.52 \mathrm{de}$ & $0.81 \mathrm{a}$ & $2.41 \mathrm{~cd}$ & 64.19 & 69.63 \\
\hline LSD & 0.4 & & 0.43 & & 0.38 & & 0.41 & & & \\
\hline
\end{tabular}

Means denoted with the same letter and within each column are not significantly different $(p \geq 0.05)$. LSD $=$ Least Significant Difference. NS $=$ Not significantly different. $\mathrm{PH}=$ plant height, $\mathrm{SDW}=$ shoot dry weight, $\mathrm{SDS}=$ salinity damage score, $\mathrm{SFW}=$ shoot fresh weight, $\mathrm{K}^{+}=$potassium content, $\mathrm{Na}^{+}=$sodium content.

Table S4. Analysis of variance results on the different growth and yield components in 11 rice genotypes under salt stress.

\begin{tabular}{cccccccc}
\hline Parameters & Source of variation & d.f. & s.s. & m.s. & v.r. & F pr. & \\
\hline Tillers plant $^{-1}$ & Genotype & 10 & 450.758 & 45.076 & 22.71 & $<.001$ \\
& Salt concentration & 1 & 40.97 & 40.97 & 20.64 & $<.001$ \\
& Interaction & 10 & 11.364 & 1.136 & 0.57 & 0.827 & NS \\
\hline
\end{tabular}




\section{Continued}

\begin{tabular}{|c|c|c|c|c|c|c|c|}
\hline \multirow[t]{3}{*}{ Plant height } & Genotype & 10 & 3263.67 & 326.37 & 5.39 & $<.001$ & \\
\hline & Salt concentration & 1 & 1196.38 & 1196.38 & 19.77 & $<.001$ & \\
\hline & Genotype & 10 & 803.79 & 80.38 & 1.33 & 0.247 & NS \\
\hline \multirow[t]{3}{*}{ SDW } & Genotype & 10 & 22.9523 & 2.2952 & 8.30 & $<.001$ & \\
\hline & Salt concentration & 1 & 9.5608 & 9.5608 & 34.57 & $<.001$ & \\
\hline & Interaction & 10 & 6.3697 & 0.6370 & 2.30 & 0.029 & * \\
\hline \multirow[t]{3}{*}{ SFW } & Genotype & 10 & 453.447 & 45.345 & 21.27 & $<.001$ & \\
\hline & Salt concentration & 1 & 70.991 & 70.991 & 33.31 & $<.001$ & \\
\hline & Interaction & 10 & 19.946 & 1.995 & 0.94 & 0.511 & NS \\
\hline \multirow[t]{3}{*}{ SFW/SDW } & Genotype & 10 & 25.187 & 2.519 & 1.79 & 0.092 & NS \\
\hline & Salt concentration & 1 & 0.189 & 0.189 & 0.15 & 0.700 & NS \\
\hline & Interaction & 10 & 24.483 & 2.45 & 2.03 & 0.054 & NS \\
\hline \multirow[t]{3}{*}{ shoot $\mathrm{K} / \mathrm{Na}$} & Genotype & 10 & 2.2346 & 0.2235 & 4.02 & $<.001$ & \\
\hline & Salt concentration & 1 & 5.2776 & 5.2776 & 95.04 & $<.001$ & \\
\hline & Interaction & 10 & 0.8562 & 0.0856 & 1.54 & 0.159 & NS \\
\hline \multirow[t]{3}{*}{ Chlorophyll } & Genotype & 10 & 8.4643 & 0.84643 & 12.63 & $<.001$ & \\
\hline & Salt concentration & 1 & 10.48015 & 10.48015 & 156.35 & $<.001$ & \\
\hline & Interaction & 10 & 3.23885 & 0.32388 & 4.83 & $<.001$ & $* * *$ \\
\hline \multirow[t]{3}{*}{ Shoot $\mathrm{K}^{+}$} & Genotype & 10 & 1.06295 & 0.10629 & 1.96 & 0.063 & \\
\hline & Salt concentration & 1 & 2.55667 & 2.55667 & 47.24 & $<.001$ & \\
\hline & Interaction & 10 & 4.28678 & 0.42868 & 7.92 & $<.001$ & $* * *$ \\
\hline \multirow[t]{3}{*}{ Shoot $\mathrm{Na}^{+}$} & Genotype & 10 & 3.92501 & 0.3925 & 6.3 & $<.001$ & \\
\hline & Salt concentration & 1 & 39.74982 & 39.74982 & 638.22 & $<.001$ & \\
\hline & Interaction & 10 & 2.13048 & 0.21305 & 3.42 & 0.002 & ** \\
\hline
\end{tabular}

${ }^{*}$, = significant at $\leq 0.05^{* *}=$ significant at $\leq 0.01$. N.S $=$ not significant. $\mathrm{SDW}=$ shoot dry weight, $\mathrm{SDS}=$ salinity damage score, $\mathrm{SFW}=$ shoot fresh weight, $\mathrm{K}^{+}$ $=$ potassium content, $\mathrm{Na}^{+}=$sodium content . 